\title{
〔論文〕
}

\section{台湾における省籍の違いに着目した商店街景観認知の 評価分析}

\author{
Evaluation of Streetscape-Consciousness in terms of the \\ Difference of Provinces in Taiwan
}

Shu-Huei LIU : University of Tsukuba 劉淑恵* Yasushi ASAMI : University of Tokyo 浅見 泰司**

With the focus on the shopping street, this study tries to search and analyze the influences of province on the evaluation of shopping streetscape in Tainan. Through questionnaires of streetscape - consciousness, a comparison of landscape of shopping street is made. According to the result, the provincial difference occurred on 1980s more than on 1930s, when compared with 1930s streetscape - consciousness and 1980s streetscape consciousness. In particular, "Benshen" and "Waishen" tend to have different view in monotony of the 1930s streetscape, and "Benshen" and "Keja" tend to have different view in familiarity of the 1980s streetscape. These differences may be caused due to the change in the attitude of "Benshen" toward the environment of cities in Taiwan.

Keywords : Province, Streetscape-consciousness, Shopping street 省籍, 商店街景観認知, 商店街

\section{1.はじめに}

本論文では, 台湾における省籍の違いによる商 店街景観の認知を, 台南市の 4 商店街の1930年代 と1980年代の写真に対する評価に関するアンケー 卜調査から分析する。省籍とは, 台湾における人々 のルーツのことであり，15世紀から20世紀初期に かけて中国南東部などから移住した本省人と客家 人 ${ }^{1)}$, そして第二次世界大戦後, 台湾に移住した 外省人などの区別を表す。戒厳令のもとでは，主
として支配階級に多かった外省人と被支配階級に 多かった本省人, 客家人という社会構造が続いて いた。しかし，外省人にはいずれ中国大陸に帰る という意識を持っていた者も多く，台湾は一時的 に滞在する仮の宿という意識があった ${ }^{2)}$ 。そのた めに，都市景観に対してもさほど強い改善意識が なかった可能性もある。戒厳令解除後は，外省人 において，それまでの仮宿的意識から，永住する 土地としての意識へという変化が徐々に進んで いった。そのため，都市を自分の物としてよりよ

劉淑恵* (りゅうしゅくえ) 正会員・筑波大学農学研究科

浅見 泰司**（あさみ やすし）正会員・東京大学 空間情報科学研究センター 
く改善していく意識が強化されていったと思われ る。

そこで，省籍の違いによって，都市景観を判断 する傾向がどのように異なるか，また，特に何に 着目して判断を下しているかを調べ，無意識に反 映するであろうと考えられる省籍の差異に基づく 都市観の違いがどのように表れるのかについて考 察してみたい。

\section{2. 省籍ごとのまちの景観構造と意識の 歴史的経緯}

\section{(1)台湾における省籍をめぐる歴史的経緯}

面積約 3.6 万 $\mathrm{km}^{2}$ の台湾は, 少なくとも 100 年前ま
では中国大陸の統治者の目に入らなかった「化外 の地(1)」であった。百年後, なぜ台湾の国際的地 位と国内省籍の紛争が焦点になったのだろうか。 元大統領の李登輝氏は省籍を問わずにみな (1998.12.04, 台北市市長選挙のキャンペーンにて) 「新台湾人(2)」と宣言した。あえて省籍の問題を表 に出さなければならなかったのは, 歴史的な経緯 から省籍間の衝突と差異があったためである。

1945年から台湾島は住民達が大統領の直接選挙 を行う1988年まで, 蒋介石氏の「蒋氏王朝」を主 とした国民党の統治下にあり，政治の力で外省人 と本省人の社会地位の格差は拡大していった ${ }^{3)}$ 。 1997年, 世新大学の李篠峰教授は「台湾に移動し

表 1 台湾における省籍の違いによる意識差異一覧表

\begin{tabular}{|c|c|c|c|c|c|}
\hline & 出自と意識 & 社会構造 & 人口構成 & 住宅街の景観構造 & 景観の捉え方の仮説 \\
\hline 省 & $\begin{array}{l}1.15 \text { 世紀から } \\
17 \text { 世紀を経 } \\
\text { て台湾へ移 } \\
\text { 住。 } \\
\text { 2.主に中国の東 } \\
\text { 南にある福建 } \\
\text { 省から移住。 } \\
3.19 \text { 世紀中期か } \\
\text { ら台湾に定 } \\
\text { 住。 } \\
\end{array}$ & $\begin{array}{l}1.1980 \text { 年代までは } \\
\text { 政治上の被統治 } \\
\text { 階及。 } \\
\text { 2.就職状况:自営業 } \\
\text { と個人企業に集 } \\
\text { 中。 } \\
\text { 3.所得は最も低い。 } \\
\text { 4. 目語 : 口南語 }\end{array}$ & $70 \%$ (1992) & $\begin{array}{l}\text { 1. 「閩南村」につい } \\
\text { ては、家の屋根の } \\
\text { 形は一種の財力の } \\
\text { 証しととらえ、派 } \\
\text { 手にする傾向。 } \\
\text { 2. 磨揚でかつオー } \\
\text { プンな性格から町 } \\
\text { 並みも䑜にに見え } \\
\text { る。 }\end{array}$ & 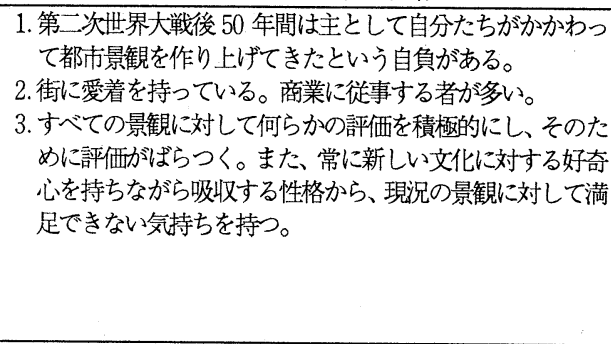 \\
\hline 人 & \begin{tabular}{|l}
$1.1945 \sim 1949$ \\
年から蒋介石 \\
氏と一緒に中 \\
国から台湾に \\
移住。 \\
2.1990 年まで \\
は中国へ戻り \\
たい気持が強 \\
かった。 \\
3.中国人である \\
意識がなおお続 \\
いている。 \\
\end{tabular} & $\begin{array}{l}1.1945-1980 \text { 年代 } \\
\text { 間で政治上の統 } \\
\text { 治階級。 } \\
\text { 2.就膱状況:軍、公 } \\
\text { 教育に集中して } \\
\text { いる。産業別で } \\
\text { はサービス業に } \\
\text { 集中。 } \\
\text { 3.所得は最も多い } \\
\text { 方。 } \\
\text { 4.母語: 北京語 }\end{array}$ & $13 \%(1992)$ & 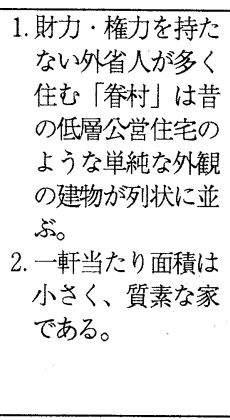 & 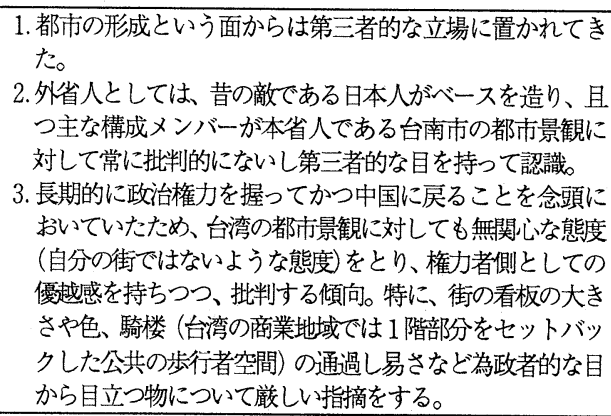 \\
\hline 人 & $\begin{array}{l}\text { 1.台湾に移住し } \\
\text { た時期につい } \\
\text { ては閵南人 } \\
\text { (本省人) } \\
\text { ほほ同時期。 } \\
\text { 2. 主に広東省か } \\
\text { らの移住。 } \\
\text { 3.19世紀中期 } \\
\text { から台湾に移 } \\
\text { 住した。 }\end{array}$ & 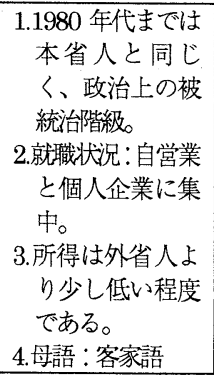 & $15 \%(1992)$ & $\begin{array}{l}\text { 1. 「客家荘」はスズ } \\
\text { ×の尻尾に似た屋 } \\
\text { 根の端部が特徴 } \\
\text { 的。 } \\
\text { 2. 町あるいは家の周 } \\
\text { りが清潔であるこ } \\
\text { とが般的。 }\end{array}$ & 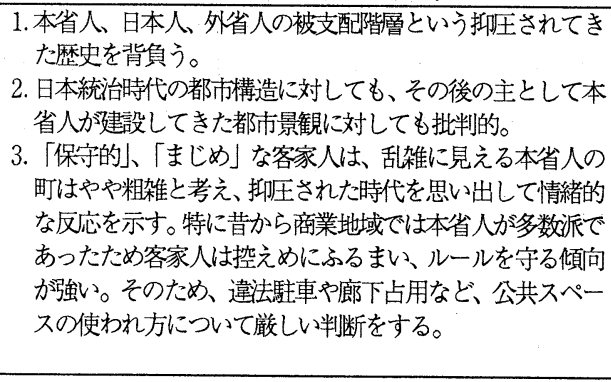 \\
\hline
\end{tabular}


た国民党政権はあくまでも中国を中心とする思想 であった。隔離政策（軍春村 ${ }^{(3)}$ の設置）と軽視政 策（台湾語の抑制）によって，外省人と台湾人の 交流が平行線になり，数十年住んでも台湾を認め がたい状況になってしまった。と語った4)。この ような背景で国民党と一緒に台湾に移住した外省 人の大半が当時の政治・経済の中心地域の台北市 に集中して住んでいる。その他は軍隊と一緒に移 動したため, 台南市に移住した外省人は少なかっ たと推定できる。

1992年時点で本省人 $14,324,508$ 人 $(70 \%)$, 客家 人 $3,058,962$ 人 $(15 \%)$, 外省人 $2,658,805$ 人 $(13 \%)$ であった ${ }^{56)}$ 。その後, 前述したように省籍はセン シティブな政治問題となって，政府側が正式的に 祖籍（中国の籍）の調査をしない方針となった。

\section{(2)省籍ごとの街の景観構造}

特定の省籍が構成する住宅街（例えば本省人の

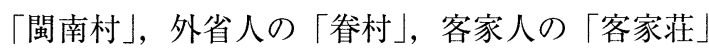
など(4) ) では各々特徵的な風貌が現れる。屋根の 形，街並みなどの外観からおおよそどの省籍の集 まりか判別できる。表 1 に示すように，本省人は 歴史的に豊かな平原に住み続けてきたことにより 資本は豊かで商売上手な傾向をもつ ${ }^{7)}$ 。人口が多 く，ものに対する所有権意識が強い。ただし，相 続によって資本は豊かだが，省籍別の比較の中で は本省人のフローの所得は最も低い方である。屋 根の形は一種の財力の証しとしてとらえられ，で きるだけ派手にする傾向がある ${ }^{8)}$ 。また，外省人 が多く住む「春村」は一軒当たり面積の小さな, 質素な家である。これは少なくとも70年代までは

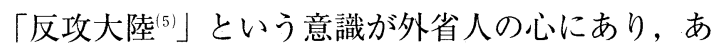
くまでも台湾島は一時的に滞在する仮の宿と考え たためである ${ }^{7}$ 。そのために本省人と客家人は外 省人を「過路客 $\left.{ }^{(6)}\right\rfloor$ と呼ぶこともあった ${ }^{4)}$ 。客家荘 では，家の周りが清潔で，よく整理していること が伺われる。家の色彩は単調で，屋根の端部がス ズメの尻尾に似ていることが特徴的である。

(3)省籍ごとの都市の景観評価に関する仮説
以上のような省籍による歴史的経緯や文化の違 いは，都市の景観評価に対しても微妙に異なって 現れると思われる。

今回の研究対象とした台南市は日本統治時代に 都市の骨格が形づくられ，それをべースとして主 に本省人が建築改変を繰り返した都市の歴史をも つ。そのため, 外省人は, 権力者側としての優越 感 ${ }^{(7)}$ を持ちながら，昔の敵である日本人がベース を造り，かつ主な構成メンバーが本省人である台 南市の都市景観に対して常に批判的にないし第三 者的な目を持って認識してきたと思われる。

表 1 に示すように本省人の場合には外省人より は，街に愛着を持っていると考えられる。また， 常に新しい文化に対する好奇心を持ちながら吸収 する性格からは，現況の景観に対して満足できな い気持ちを持つ傾向があるだろう ${ }^{7) 。 ~}$

「東洋の工ダヤ人」と言われる客家人 ${ }^{(8)} の$ 場合 は ${ }^{9)}$, 本省人, 日本人, 外省人の被支配階層とい う抑圧されてきた歴史を背負っているため，日本 統治時代の都市構造に対しても, その後の主とし て本省人が建設してきた都市景観に対しても，批 判的に見つめる傾向があると思われる。そのため, 結果的には外省人と類似して, 都市景観について も批判的な判断が多い可能性もある。因みに, 前 述したような歴史の影響もあって，過去の調査に おいて，抑制的にならざるを得なかった客家人は 自分の省籍を明瞭に示さない傾向がみられた ${ }^{10)}$ 。

以下ではこれらの仮説について検証し, かつ日 本の残した都市計画的な骨格（30年代）とその後 の台湾における主要街路での建築的変革 $(80$ 年代) が現在の台湾の居住者にとってどのように捉えら れるのかを景観の面から考察する。

\section{3. 既往研究}

台湾では都市景観に関する評価研究については, 1987年の街路を対象とした景観制䘖に関する研究 がある111。この論文は専門家にアンケート調査を 行い，それを単純集計してまとめた研究である。 
その後，蔡が1993年から街路の看板問題に着目し て一連の研究を行なった。看板を機能面から 4 つ の類型にまとめ，法令に基づいて記述し ${ }^{12)}$ ，翌年， 都市景観の観点から広告看板の設置とその影響の 研究を上, 下篇で, 専門誌に発表している。研究 内容と手法は前述と変わりなく, 概説的な記述に とどまっている13)。1994年，郭がアニメーション と視鸴模擬を用いて都市景観に刘する評価を行っ

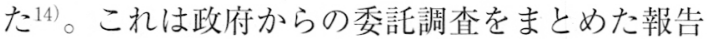
書である。 2 年後, 審査付きの論文が発表された。 研究内容はパソコンを用いた動画の視知覚評価で ある。すなわち，3 通路について視覚の複雑度と 空間秩序に基づいて 9 つの通路景観をアニメー ション化し，これを用いて学生を対象として意識 調査を行った ${ }^{15)} 。 1995$ 年にも学生の論文で景観を 模擬評価として景観の制度面での研究があった ${ }^{16)} 。$ また林と章は，DanielとBosterが1976年に提案し た定量的手法である「景観美質評估法（Scenic Beauty Estimation)」という評価システムを，台 湾のまちづくりに応用している $\left.{ }^{17)} 18\right)$ 。その他, 既 存研究には都市景観に関する好みの研究なども あった。これらは学生へのアンケート調查を通し て, 因子分析から得た結果をまとめた研究であ る19)。住民へのアンケート調査を対象としての研 究調査もあった。しかし，これは単に公園の景観
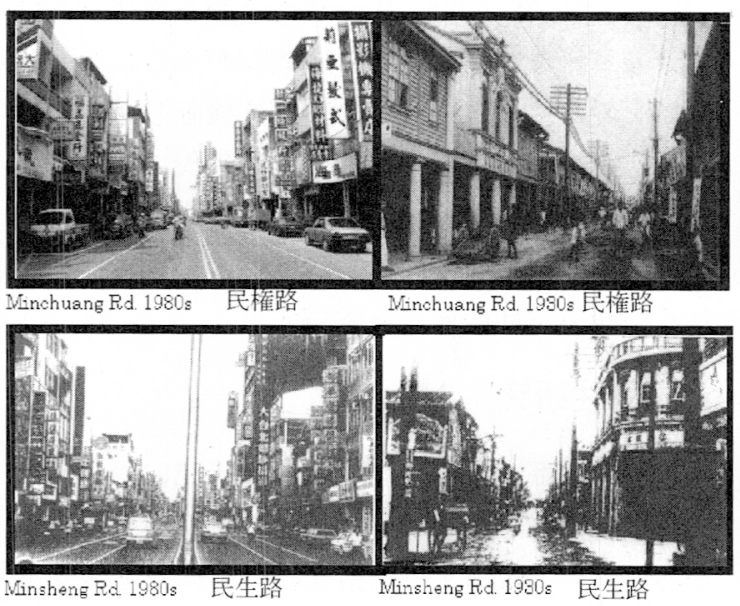

図 24 つの街路の 30 年代と 80 年代の景観写真 る $^{(920)}$ 。

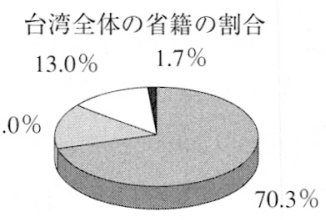

図 1 省籍の割合

の維持に関する参加意欲の有無に関するものであ

本研究とのかかわりでは, 台湾の都市景観に関 する評価研究は，概説的な研究が多い。近年，定 量的分析や心理的効果の解析などが行われている が，景観意識を省籍と結びつけた研究例はない。 省籍に関しては，社会的な研究は数多〈ある ${ }^{6)}$ 。

しかし，台湾の省籍にかかわる社会構造が都市景 観に及ぼす影響を考察したものはない。

\section{4. 研究方法と対象商店街}

対象地域は, 台湾の古都『台南』である。台南 市民政局戸政課の統計資料によると 2000 年 4 月現 在の総人口数は約 73 万人である。台南は日本の『京 都』と似た存在で, 現代化しつつある台南の繁華

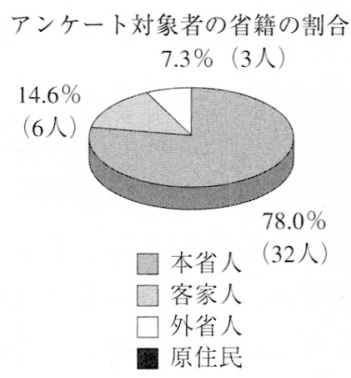

参考：参考文献 5 )

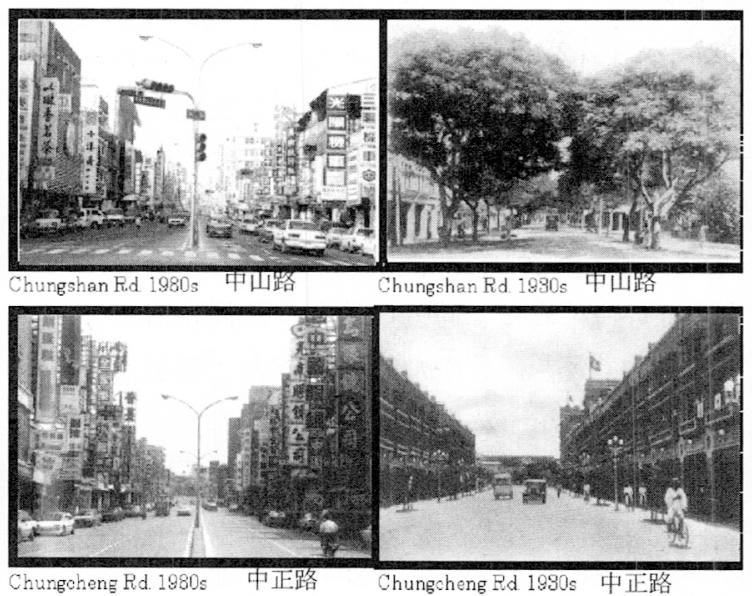


街には同時に伝統的外観を持つ商店街が共存して いる。

本研究では，同じ場所の商店街について，30年 代と80年代の写真を用いて, 景観要素と構造など のアンケート調査を行う。アンケートは, 内容が やや高度で専門的な知識も若干必要であるという 判断から, 国立成功大学の都市計画系の学生に対 して行った。20代の大学生にアンケートしたのは, 約10年前の1987年が大統領が外省人から台湾出身 の李登輝氏に変わった年であり, 彼らがその時に ちょうど多感な時代を送っていた年齢層であるた めである。

前述 4 つの商店街としては, 台南市の市中心に 位置し，歴史的な意味をもつ商店街と思われる民 権路, 民生路, 中山路, 中正路の 4 つの代表的な 商店街を対象地区として選定した。図 2 に示すよ うに50年にわたる空間の変化が大きく街の雲囲気 を変えている。各々の街ごとに 30 と 80 年代の写真 は同じ方向，場所のものとした。30年代の写真は 白黒だったため80年代の写真も白黒に変換した。 30年代の写真を見ればそれぞれの街の機能がはっ きり違っていたことがわかる。しかし，80年代の 写真では各々の街の機能が同一であるように見え る。

時の変遷によるこの 4 つの商店街の変化に基づ いて, 各々の街に関する景観要素を抽出し，20代 の大学生がどのように感じているのかをアンケー 卜調査で調べた。1997年 2 月, 成功大学都市計画 学系の学生 45 名 ${ }^{(10)}$ に 3 版一枚に載った 8 枚の景 観写真（図 2 ）21）を見ながら，それぞれ該当する アンケート用紙A 4 の 8 枚で, 表 3 に示す 17 個の 形容詞対について景観印象の当てはまり度を 7 段 階(1122) で答えてもらい，さらに表 $4-1$ および表 $4-2$ に示すような景観要素の中から, それぞれ の形容詞対に関する回答を何に着目して答えたの かの理由付けとして, 該当するものすべてを記入 してもらった。各形容詞対における理由付けとし ては，まず商店街の街路景観として主な要素であ
る建物とそれ以外の要素に分けて, 次にその各々 を物的要素と質的要素に分けて, 計 4 分類19項目 を選定した。これらの項目の内容はできるだけ街 にふさわしくかつ回答者も分かりやすいように設 定した。しかし，省籍を問わずに各々の写真に対 する形容詞対毎に，19項目の中から選ばれなかっ た項目とわずかな人数が選んだ項目を削除した結 果, 残りは表 4-1に示すような 7 種類となった。 4 名の学生が省籍の欄を空白で答えた。その結果, 41名の対象者における省籍の割合は図 1 に示した ように客家人と外省人はそれぞれ 6 人 (14.6\%) と 3 人 $(7.3 \%)$ にすぎない。本省人は絶対多数の 32 人 $(78 \%)$ を占めている。

図 1 に示したように, 特に外省人のサンプル数 が少ないことは分析力を高めるには弊害となって いる。しかし，省籍による差別をなくすために， 省籍を明らかにしようとしない風潮を鑑みると， 大規模にこのような調查を行うことは極めて難し い。したがって, 本研究で得られたデー夕は限ら れたものであるが貴重であるので, 少しでも有意 義な傾向を読みとることを目指して分析を行うこ ととした。

\section{5. 分析方法と結果}

四つの商店街の中で，80年代と 30 年代の有効回 答数の多い民権路を省籍差異の分析対象とした。 省籍を変数として, 対象商店街の景観に対する形 容詞対による評価と，その理由付けとしての景観 要素に関して分析を行う。1）７段階の尺度評価 における形容詞対17対中の16対（個別印象という よりも総合的な印象となってしまう「全体として よい／悪い」を除く）を計算分析の対象とした (表 3 ） 2324)。2）前述のように, 各形容詞対にお ける理由付けとして, 回答者に選ばれなかった理 由付け（表 4-2）を除いて, 高い順から多く選ば れた 7 つの理由付けを選び出す（表 4-1）。カイ 二乗計算 ${ }^{(2)} て ゙$ 省籍が景観に対する感覚に及ぼす影 響を探り出し，カイ二乗検定を行った ${ }^{(1325) 。}$ 
表 3 形容詞対一覧表

\begin{tabular}{|c|c|c|c|}
\hline $\begin{array}{ll}\text { 1. 豪華な/ } \\
\text { 素朴な } \\
\text { 5. 個性的/ } \\
\text { 個性的でない } \\
\text { 9. 親しみやすい } \\
\text { 親しみにくい } \\
\text { 13. 歴史性のある } \\
\text { 歴史性のない } \\
\text { 17. 全体として良い }\end{array}$ & 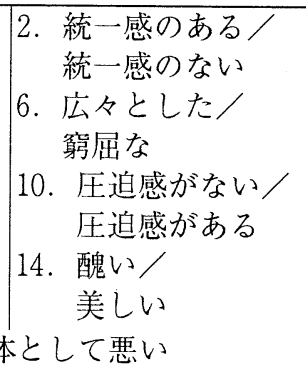 & 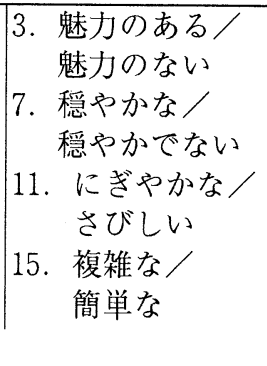 & 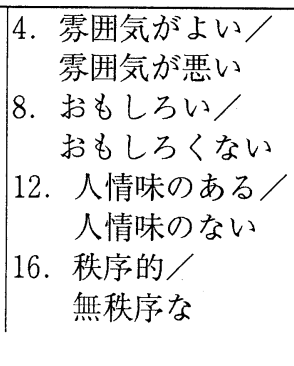 \\
\hline
\end{tabular}

表 4-1 選ばれた各々の形容詞対の理由付け一覧表

\begin{tabular}{|l|l|}
\hline $\mathrm{A}:$ 建物の物的要素(Building's physical elements) & 看板 $(\mathrm{X} 1)$ \\
\hline $\mathrm{B}:$ 建物の質的要素(Building's property elements) & $\begin{array}{l}\text { 高さ、広さ、外観、材質、建物の歴史 (X2) } \\
\text { 空のタイプ、材質、規模 }(\mathrm{X} 3)\end{array}$ \\
\hline $\mathrm{C}:$ その他の物的要素(Other feature's physical elements) & $\begin{array}{l}\text { 電線 (X4) } \\
\text { 違反駐車 (X5) } \\
\text { 路面 (X6) }\end{array}$ \\
\hline D：その他の質的要素(Other feature's property elements) & 街灯の明るさ、高さ、アート (X7) \\
\hline
\end{tabular}

表 4-2 選ばれなかった各々の形容詞対の理由付け一覧表

\begin{tabular}{|l|l|}
\hline A：建物の物的要素(Building's physical elements) & 1) 屋根 2) 空 3) 廊下 4) 柱 \\
\hline B：建物の質的要素(Building's property elements) & 1) 看板の色彩・高さ・大きさ文字・材質 2) \\
& 廊下の高さ・広さ・形 3) 屋根の型・色彩 \\
\hline C: その他の物的要素(Other feature's physical elements) & 1) 電柱 2) 街灯 3) 道の幅 4) 街路樹 \\
\hline D: その他の質的要素(Other feature's property elements) & 1) 路面の舗装材料、色彩 \\
\hline
\end{tabular}

\section{(1)省籍における80年代の商店景観に対する評価の 差異}

カイ二乗分析の結果から商店景観の形容詞対に 対する省籍の差異は有意水準10\%以下となる項目 が少なかった。16形容詞対の半数以上において有 意水準 $10 \%$ 以上となっていた。本省人と外省人の 80年代商店街景観に対する評価においては有意な 差は少ないが，「広々とした／窮屈な」(有意確率 （以下，同じ）：0.071）と「人情味のある／人情味 のない」(0.086) で若干の差があった。また, 客 家人と本省人の間も「親しみやすい／親しみにく い」（0.039）と「圧迫感がある/圧迫感がない」 （0.025）では有意な差異があった（表 5 ）。客家人 と外省人の回答傾向は類似していた。差異が少な いながら, 客家人と本省人, また外省人と本省人
の差異が有意であった。客家人と外省人の回答者 数が少ないにもかかわらず有意であったことは, それぞれの項目についての差異はやや顕著であっ たと考えて良い。有意確率の平均值からみると， 省籍における 80 年代の商店街景観に対する「雲囲 気がよい/䨌囲気が悪い」という見方は他の形容 詞対よりも差異がなかった。

\section{(2)省籍における80年代商店街景観に対する理由付 けの差異}

80年代商店景観における各形容詞対の理由付け の差異は次の傾向を示した。外省人と客家人，ま た本省人と客家人の回答傾向の差異に関しては有 意水準10\%以下となる項目がなかった。本省人と 外省人の差異が前述の二組の差異よりも顕著で あった。特に「統一感のある/統一感のない」(有 
表 5 省籍による商店街景観に対する評価の差異

\begin{tabular}{|c|c|c|c|c|c|c|c|c|}
\hline & $\begin{array}{c}80 \text { 年代 } \\
\text { 客 vs. } \\
\text { 本 }\end{array}$ & $\begin{array}{c}\text { 本 vs. } \\
\text { 外 }\end{array}$ & $\begin{array}{c}\text { 外 vs. } \\
\text { 客 }\end{array}$ & $\begin{array}{c}\text { 平均 } \\
\text { 値 }\end{array}$ & $\begin{array}{c}30 \text { 年代 } \\
\text { 客 vs. } \\
\text { 本 }\end{array}$ & $\begin{array}{c}\text { 本vs. } \\
\text { 外 }\end{array}$ & $\begin{array}{c}\text { 外vs. } \\
\text { 客 }\end{array}$ & $\begin{array}{c}\text { 平均 } \\
\text { 值 }\end{array}$ \\
\hline 1 豪華な／素朴な & 0.923 & 0.683 & 0.710 & 0.772 & 0.972 & 0.978 & 0.996 & 0.982 \\
\hline 2 統一感のある／統一感のない & 0.836 & 0.504 & 0.321 & 0.554 & 0.917 & 0.857 & 0.959 & 0.911 \\
\hline 3 魅力のある/魅力のない & 0.470 & 0.916 & 0.854 & 0.747 & 0.878 & 0.306 & 0.895 & 0.693 \\
\hline 4 雾囲気がよい/雾囲気が悪い & 0.827 & 0.875 & 0.993 & 0.898 & 0.243 & 0.905 & 0.809 & 0.652 \\
\hline 5 個性的／個性的でない & 0.133 & 0.699 & 0.423 & 0.419 & 0.480 & 0.971 & 0.959 & 0.804 \\
\hline 6 広々とした／窮屈な & 0.350 & 0.071 & 0.959 & 0.460 & 0.616 & 0.148 & 0.345 & 0.370 \\
\hline 7 穏やかな/穏やかでない & 0.814 & 0.289 & 0.345 & 0.483 & 0.522 & 0.224 & 0.609 & 0.452 \\
\hline 8 おもしろい/おもしろくない & 0.456 & 0.962 & 0.895 & 0.771 & 0.726 & 0.545 & 0.423 & 0.565 \\
\hline 9 親しみやすい／親しみにくい & 0.039 & 0.916 & 0.423 & 0.460 & 0.506 & 0.976 & 0.895 & 0.792 \\
\hline 10 圧迫感がない／圧迫感がある & 0.025 & 0.292 & 1 & 0.439 & 0.938 & 0.303 & 0.710 & 0.651 \\
\hline 11 にぎやかな/さびしい & 0.729 & 0.537 & 0.999 & 0.755 & 0.694 & 0.355 & 0.345 & 0.464 \\
\hline 12 人情味のある/人情味のない & 0.763 & 0.086 & 0.174 & 0.341 & 0.266 & 0.984 & 0.993 & 0.748 \\
\hline 13 歴史性のある／歴史性のない & 0.518 & 0.872 & 0.809 & 0.733 & 0.881 & 0.940 & 0.993 & 0.938 \\
\hline 14 醜い／美しい & 0.513 & 0.977 & 0.854 & 0.781 & 0.060 & 0.791 & 0.809 & 0.553 \\
\hline 15 複雑な／簡単な & 0.596 & 0.128 & 1 & 0.575 & 0.288 & 0.255 & 1 & 0.514 \\
\hline 16 秩序的/秩序的でない & 0.367 & 0.916 & 1 & 0.761 & 0.783 & 0.840 & 1 & 0.874 \\
\hline
\end{tabular}

註 : 表の中の值は有意確率で、有意水準は $10 \%$ とし、小さいほど有意な差があることを示す。

略字の説明／本：本省人、外：外省人、客：客家人 (以下同じ)

表 6 省籍による商店街景観に対する理由付けの差異

\begin{tabular}{|c|c|c|c|c|c|c|c|c|}
\hline & $\begin{array}{c}80 \text { 年代 } \\
\text { 客 vs. } \\
\text { 本 }\end{array}$ & $\begin{array}{c}\text { 本vs. } \\
\text { 外 }\end{array}$ & $\begin{array}{c}\text { 外vs. } \\
\text { 客 }\end{array}$ & $\begin{array}{c}\text { 平均 } \\
\text { 值 }\end{array}$ & $\begin{array}{c}30 \text { 年代 } \\
\text { 客 vs. } \\
\text { 本 }\end{array}$ & $\begin{array}{c}\text { 本 vs. } \\
\text { 外 }\end{array}$ & $\begin{array}{c}\text { 外vs. } \\
\text { 客 }\end{array}$ & $\begin{array}{c}\text { 平均 } \\
\text { 値 }\end{array}$ \\
\hline 1 豪華な／素朴な & 0.931 & 0.728 & 0.703 & 0.788 & 0.791 & 0.240 & 0.469 & 0.500 \\
\hline 2 統一感のある／統一感のない & 0.597 & 0.084 & 0.264 & 0.315 & 0.359 & 0.386 & 0.020 & 0.255 \\
\hline 3 勉力のある／魅力のない & 0.929 & 0.787 & 0.743 & 0.820 & 0.752 & 0.396 & 0.324 & 0.491 \\
\hline 4 雾囲気がよい/雾囲気が悪い & 0.565 & 0.440 & 0.322 & 0.442 & 0.895 & 0.531 & 0.728 & 0.718 \\
\hline 5 個性的/個性的でない & 0.348 & 0.427 & 0.700 & 0.492 & 0.936 & 0.102 & 0.391 & 0.476 \\
\hline 6 広々とした／窮屈な & 0.267 & 0.819 & 0.573 & 0.553 & 0.243 & 0.061 & 0.301 & 0.202 \\
\hline 7 穏やかな/穏やかでない & 0.456 & 0.871 & 0.772 & 0.700 & 0.285 & 0.296 & 0.160 & 0.247 \\
\hline 8 おもしろい/おもしろくない & 0.187 & 0.124 & 1 & 0.437 & 0.651 & 0.616 & 1 & 0.756 \\
\hline 9 親しみやすい／親しみにくい & 0.635 & 0.806 & 0.659 & 0.700 & 0.501 & 0.780 & 0.409 & 0.564 \\
\hline 10 圧迫感がない／圧迫感がある & 0.610 & 0.351 & 0.645 & 0.535 & 0.585 & 0.419 & 0.541 & 0.515 \\
\hline 11 にぎやかな／さびしい & 0.803 & 0.065 & 0.854 & 0.574 & 0.598 & 0.913 & 0.664 & 0.725 \\
\hline 12 人情味のある/人情味のない & 0.648 & 0.067 & 0.745 & 0.487 & 0.265 & 0.920 & 0.550 & 0.578 \\
\hline 13 歴史性のある／歴史性のない & 0.537 & 0.862 & 0.309 & 0.569 & 0.489 & 0.859 & 0.746 & 0.698 \\
\hline 14 醜い／美しい & 0.778 & 0.129 & 0.314 & 0.407 & 0.320 & 0.452 & 0.175 & 0.316 \\
\hline 15 複雑な／簡単な & 0.289 & 0.011 & 0.408 & 0.236 & 0.164 & 0.218 & 0.338 & 0.240 \\
\hline 16 秩序的/秩序的でない & 0.832 & 0.078 & 0.168 & 0.359 & 0.811 & 0.486 & 0.426 & 0.574 \\
\hline
\end{tabular}


統一感のある/統一感のない

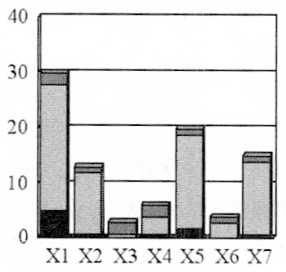

外省人鿷本省人
にぎやかなノさびしい

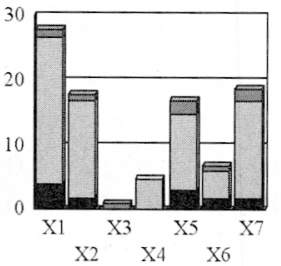

人情味のあるノ人情味のない

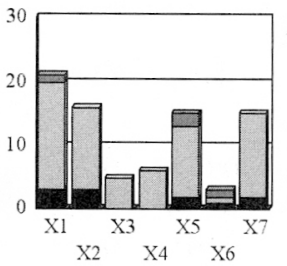

複雑な /簡単京

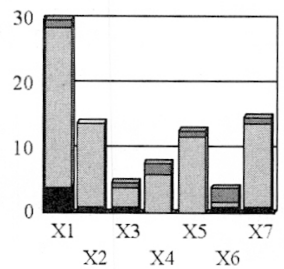

秩席的 /無秩序去

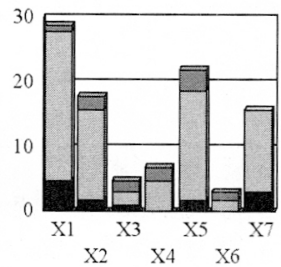

図 380 年代省籍による商店街景観に対する形容詞対の理由付けの場合

統一感のある/統一感のない

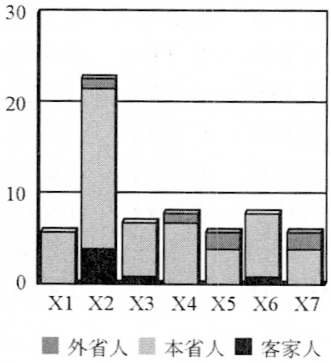

庆々とした筷屈な

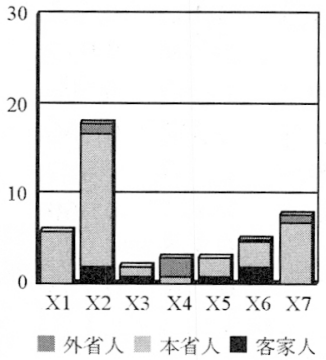

図 430 年代省籍による商店街景観に対する形容詞 対の理由付けの場合

意確率（以下，同じ）：0.084），「にぎやかなノさ びしい」(0.065)，「人情味のある／人情味のない」 (0.067) ,「複雑な 簡単な」(0.011),「秩序的 /無 秩序な」(0.078) 等の項目について, 差異が高い と言える (表 6 )。表 6 に示したように, 有意確率 の平均値から省籍を問わずに80年代の商店街景観 の理由付けに対する差異が最も小さい形容詞対は 「魅力のある/魅力のない」であった。

(3)省籍における30年代の商店景観に対する評価の 差異

分析結果によると省籍の街路景観に対する形容 詞対の評価差異は80年代より更に少ない。表 5 に 示したように有意確率がかなり高く, 有意水準 $10 \%$ 以下となる項目は本省人対客家人の「醜い 美しい」（有意確率：0.060）だけであった。それ に次いで差異があったのは本省人と外省人の 「広々とした／窮屈な」(0.148) であった。表 5 に 示したように，省籍による古都台南の 30 年代の商

店街景観に対する評価差異が顕著でなかったのは 「豪華な/素朴な」(0.982) と「歴史性のある/歴 史性のない」（0.938）である。

\section{(4)省籍における30年代商店景観に対する理由付け の差異}

30年代の商店街景観に対する各形容詞対の理由 付けの差異は，分析結果は有意水準10\%以下とな る項目が二つしかなかった。それは外省人対客家 人の「統一感のある／統一感のない」（有意確率： 0.020）と本省人対外省人の「広々とした／窮屈な」 （0.061）であった（表 6 ）。図 4 に示したように客 家人は建物の質と空の質や路面に注目したのに対 し, 外省人は大半が電線, 違反駐車, 街灯に着目 した。また，外省人は電線，街灯の方に着目する のに対し，本省人は看板，違反駐車，路面を気に した。しかしながら，80年代の商店街景観の評価 結果と異なり，理由付けの項目のうち一致してい るものは一つしかなかった(図 4)。それは80年代 の外省人対本省人と 30 年代の外省人対客家人の 「統一感のある/統一感のない」であった。有意確 率の平均值から，省籍に係わらず，30年代商店景 観に対する理由付けの差異が顕著でなかったのは 「おもしろい/おもしろくない」(0.756) であった (表 6 )。

\section{6. 結果考察}

外省人と客家人のデー夕数が小さかったものの， 回答には同じような傾向があった。客家人の人数 が少ないため, 有意でなかったからといって差異 
がないとは結論できないが，検定では有意だった ものは，かなり差異が顕著であったと言える。前 述の仮説で示したように外省人と客家人は街に対 し批判的であり，景観構造の認知上で両者の一致 性は高く，特に理由付けの項目は主に看板と建物 の内側，違反駐車に集中している。これは，第 2 章で述べたように台南市は本省人の街と言われて いることに合致しており，第 2 章で述べた仮説を 支持する結果が得られたと言えるだろう。このよ うな結果が得られた理由の一つとしては前述した ように両者の人口比率がもともと少なく，不満な ことや不平なことがあっても地域に溶け达まなけ れば生きていけない立場が色濃く出たのではない かと考えられる。これは，第 2 章で述べたように 客家人は自分の省籍を明瞭に示さない傾向がみら れたことに一致しており，また，外省人は長期的 に政治権力を握ってかつ中国に戻ることを念頭に おいていたため, 台湾の都市景観に対してもどち らかといえば無関心な態度をとり, 権力者側の意 識から批判する傾向があるという仮説にも一致し た。本省人の評価結果にはばらつきが目立つ。し かしながら全ての質問項目に対して全て回答して いる。これは自分がつくった街に対する意識の高 さの現れでもあろう。なお，全体として良いか， 悪いかという質問に対しては省籍による著しい差 異はなかった。

以下では各々の分析結果に対して検討，考察を 行う。

\section{(1)省籍における80年代の商店街景観評価}

7 つの理由付けの中で特徵的なことは, 本省人 の景観への意識がまず看板に向かうことである。 本省人は建物の内側より外観の方に注目する傾向 があった。派手な色合いで飾った屋根, 柱, きり ばりなどは昔からの本省人の建物の特色である ${ }^{26)} 。$ これも客家人の内側から外観までほほ同系色と なっているという素朴さとは異なる。商店街の中 で派手な色合いで表現できるのは看板である。分 析結果の中で本省人が商店街に対する「複雑な」
「人情のある」意識を看板と結び付けたことが本省 人の特徴をよく示していると思われる。看板の色 については色の調和を重視している西洋の景観学 と逆であるが，しかし，これこそ台湾の特徵とも 言えるだろう。「乱れの美」もしくは「台湾の美」 であるとも考えられる。本省人は自分の街に対す る愛着性を持ちながら，自分の街を「おもしろく ない」,「親しみにくい」,「混雑している」という 葛藤の気持ちもあった。しかし，その反面「人情 のある」街だという声もあった。本省人の「親切 だがやや過剩になりやすい商売本能」7）という 「思いやり」を持つ傾向を反映していると言えるの ではないだろうか。

人数の少ない外省人が選んだ理由付けは本省人 より遥かに多様なものであった。中でも違反駐車 が多く選ばれ, 次に看板, 街灯, 電柱等であった。外 省人は見た目より利便性を考慮する傾向があると 言えよう。「傍観者清」（第三者の方がよくわかる の意）という諺のように外省人は第三者の立場で, 「違反駐車と看板」を理由として, 商店街の景観を 「簡単な」,「人情のない」と批判する。外省人のも のに対する価値観の違いと，道の通過しやすさな どを気にするということが検証できたといえる。 また，外省人が商店街景観を「機能」の面から評 価する傾向を示していると考えられる。

客家人と外省人の差は少なかったが, 客家人は 歴史的な背景により生活環境に親和しやすく，好 感を持って受け入れるという点が外省人と違うと ころであった。しかしながら，80年代の商店街景 観に対しては外省人なみに批判をする傾向がある ことが確認できた（表 5 ）。

\section{(2)省籍における30年代の商店街景観評価}

分析結果からわかるように外省人と客家人の回 答傾向は差異の少ないものであった。これは, 回 答者の殆どが 20 代の大学生で, 日本統治時代への 思い入れがあまりない世代であることによると思 われる。一方, 限られたデータでも, 評価の差異 については客家人と本省人の間の「醜い／美しい」, 
理由付けの差異については外省人と客家人の間の 「統一感のある／統一感のない」と本省人と外省人 の間の「広々とした／窮屈な」において，有意な 結果が得られた。また，省籍に係わらず，古都台 南に対する「豪華な／素朴な」と「歴史性のある 歴史性のない」の評価差異がなかったことがわ かった。

日本統治時代からの建物が多く残る 30 年代の商 店街写真について，本省人と比べたところ意外に 外省人の反応は平静であった。主に電柱が外省人 の景観に対する判断の理由付けとして選ばれた。 本省人は日本時代の建物や特別な外観の街灯を選 び出した。本省人と外省人ともに美的な意味に関 連する形容詞を選び出すことについては，景観構 造という観点で素直に回答をしたと考えられる。 前述の仮説の中で, 外省人は日本的なものに情緒 的な反応を示すのではないかと述べたが，今回の 調査ではそのような傾向は見られなかった。本省 人が判断する形容詞対の理由付けとして, 建物·看 板・街灯など外観がポイントとなることはここで も検証できた。外省人が本省人と大きく異なると ころは，外省人は電柱を気にするが，本省人は気 にしないということであった。しかし，評価值の 平均とバックデー夕から，省籍にかかわらず 30 年 代の商店街景観に対しては共に好感を持っている ことがわかった。

\section{7. おわりに}

本研究では，省籍の違いによる商店街景観の認 知の差異について評価分析を行った。その結果, 30年代よりも80年代の商店街景観に対して，省籍 による大きな差異が認められた。更に，前述した ように特に外省人の数が少なかったために，外省 人と客家人との差は必ずしも有意ではなかった。 しかし,それでも有意だったものは, 差が大きかっ たと考えてょいだろう。本省人と外省人，および 本省人と客家人との間では，それぞれ有意な差異 が認められた。
まちづくりにおいて，街路景観を造るための主 体は住民である。しかし，習俗や出身また歴史的 文化的な背景など，さらに省籍に起因する複雑な 要素（政治上，経済上と教育レベルなど特に台湾 意識の有無）をもつ台湾におけるまちづくりでは 「省籍の意識」が原因となって, 合意形成が困難で

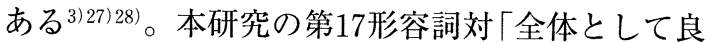
いか悪いか」のカイ二乗分析結果には差異がな かった。しかし，例えば，本省人と客家人の間で は1930年代の街に対する「醜い／美しい」の認知 差異，および本省人と外省人との間では1980年代 の街に対する「親しみやすい／親しみにくい」評 価において有意な差異が認められた。このような 認知の差異は台湾の都市環境の中の一部につなが る可能性があるので，景観に対する影響も発生し うるであろう。これらの問題を解決するには, 発 生しうる要素をできる限り取り出して, 定量的に 検証を行い，省籍による差異を最小限にする努力 をし，合意形成をはかっていく必要がある。住民 の本質的なニーズを捉え，適切にまちづくりにい かして質のよい景観や環境を造っていくことが台 湾ひいては国際社会の都市づくりにおいて，今後 の重要な課題である。

\section{〈謝辞〉}

本研究を実施するにあたって，アンケートに協力 していただいた台湾成功大学88級の学生の皆さん と担当教官の黄秋月先生，孔憲法先生，及び文化 大学 88 級学生の候佩吟氏, 筑波大学水鉋揚四郎先 生, 筑波大学天田高白先生, 所属研究室のOBの中 澤藤江，および匿名の查読者の方々より有益な情 報や助言をいただきました。また，本研究の実施 にあたり，文部科学省科学技術振興調整費の助成 を受けました。記して謝意を表します。

\section{補注}

(1)化外の地 : 未だ人の手で開発の少ない場所 (2)1998.12.29／中国時報，『……李登輝總統昨天接見「人權 
教育基金會」人權紀念碑建碑委員柏楊等人時, 透露他以前 睤經差點被情治人員抓走的一段往事, 並且強調我們要告別 悲情, 從悲情中尋找幸福, 如此悲哀也會變成幸福, 這就是 他提出「新台灣人」的意義。』

(3)軍春村：1949年中国から台湾にきた軍人又はその家族を 対象として造った村のことである。

(4)各々の省籍に特有な建物風貌
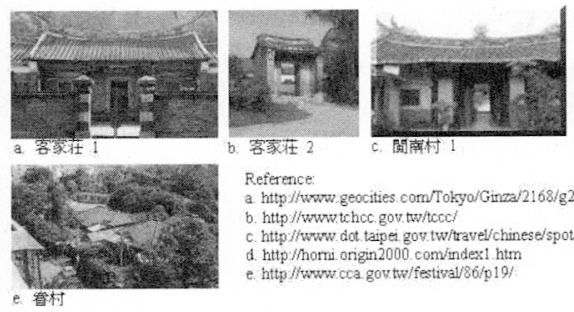

容家㾏 2

Reference

a http//Www geocities com/Tokyo/Ginza/2168/g23 htm b. htlp://www, tchcc, gov tw/tocol

c. http//www dot taipes gov tw/travel/chinese/spot/kind $9 / \mathrm{kind} 9-06 \mathrm{htm}$ d. hitp/homi origin 2000 comindex 1 htm e. http//www.cca gou tw/festival/86/p19:

(5)反攻大陸： 50 年代から 80 年代まで蒋介石が主導した国民 党政府からの政策で中国に反攻するという教育哲学があっ た。いわば民族教育における思想の改造といえる。

(6)過路客：永久の居場所にしない旅客; 外省人は台湾を永 久の居場所としないのでこのような名を付けた。

(7)「優越感を持つ外省人」: 1949年に台湾島に絶対的な統治 者の姿で現れたためいまでも大中国の情緒を持っている。 本省人の社会に溶け込みにくい状態とも言える。

(8)客家精神について，イギリスの研究家E. J. Eitelは,「一 般に中華民族は保守的な特性を持つのに対し，客家人のみ は例外的存在といえる。彼らは革命的であり, 進取の気分 にあふれている」「彼らは剛柔双方の特色を持つが, 剛毅仁 愛であると共に侮れない強暴的精神を持つ民族である」と している(「客家史綱」)。「頑固な客家人」:頑張りや且つ正 義感をもつ客家人の場合は喍るより黙って行動する人間で あろう。同参考文献の 3 )，4）参照。

(9)以上の論文のデータソースについては，1970年から1999 年初まで学生論文に関しては約6500件の卒業論文, 修士論 文, 博士論文から検索した。また, 審查付き論文と委託調 查報告書などは学会誌と専門雑誌総数約 2950 点の刊行物か ら選び出した。

(10)アンケート対象者の選定経緯 : 省籍の差異を明確に出す ためには, 日本統治時代からずっと台湾にいた高齢者をア ンケート対象者とすることも考えられる。しかし，質問内 容について専門知識のない高䶚者には難しいと判断し, ア ンケート対象者とすることを断念した。

(11)「醜い・美しい」の7 段階評価：非常に醜い, 醜い, や や醜い, どちらもない, やや美しい, 美しい, 非常に美し い。評価得点はこの順に $1 \sim 7$ とした。

(12)力イ二乗值は $\mathrm{X}^{2}=\sum_{\mathrm{i}} \Sigma_{\mathrm{j}}\left(\mathrm{O}_{\mathrm{ij}}-\mathrm{E}_{\mathrm{ij}}\right)^{2} / \mathrm{E}_{\mathrm{ij}}$ で定義される。 (ただし， $\mathrm{O}_{\mathrm{ij}}$ ：観察頻度， $\mathrm{E}_{\mathrm{ij}}$ ：期待頻度，i=1,2は省籍, $\mathrm{j}=1, \ldots, 7$ は尺度の数, $\mathrm{X}^{2}$ : カイ二乗值, 自由度 $\mathrm{df}=6$ ）省籍 による差異がないとすれば, 期待頻度は $\mathrm{E}_{\mathrm{j} j}=$ (列の総和 $\times$ 行の総和）／総サンプル数で計算される。

(13)例えば，外省人対本省人の違いについて検定する場合， それに対応する添え字を「外」「本」，X：評洒項目の頻度， $\mathrm{N}$ : 観察值の総数と $L P_{\mathrm{j} j}=\mathrm{X}_{\mathrm{ij}} / \mathrm{N}_{\mathrm{i}}(\mathrm{i}=$ 外, 本 $; \mathrm{j}=1 \sim 7$ 理由付

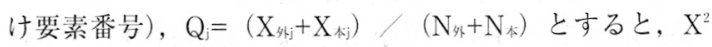
$=\mathrm{N}_{\text {外 }} \mathrm{N}_{\text {小 }}\left[\Sigma_{\mathrm{j}}\left(\mathrm{P}_{\text {外 }}-\mathrm{P}_{\text {隹 }}\right)^{2} / \mathrm{Q}_{\mathrm{j}}\right] /\left(\mathrm{N}_{\text {外 }}+\mathrm{N}_{\text {标 }}\right)$ は自由度 6 のカイ 二乘分布に従う。有意確率は小さくほど差があることを示 す。

\section{参考・引用文献}

1) 陳運棟（1994）「歴史と族群の視点からみた義民 信仰」『客家文化検討会論文集」行政院文建会

2 ）笠原政治・植野弘子（編）（1995）『台湾』河出書 房新社

3 ）点乃徳（1997）「台湾階級流動的族群差異及原因」 『台湾社会学研究』第 1 期 pp.137-167

$4 ）$ 李筰峰（1997）「最勇敢と知恵の台湾人」http： / www.gati.org.tw/articles / lee97

5 ) 施正峰（1997）「台湾の族群政治」『教授論壇專 刊』第 4 期, pp.73-108

6 ）黄士旅（2000）『台湾族群研究目録』捷幼出版社

7 ) 李光真 (1999)「外省流亡曲」『光華雑誌』12月号 p. 90

8 ）劉還月（1999）『台湾客家風土誌』常民文化出版 社

$9 ）$ 吳濁流（1977）『アジアの孤児』遠行出版社（台 湾版)

10）張瓊方（1998）「也是原郷」『光華雑誌』4 月号 p. 50

11）黄漢洲（1987）「都市街路の景観制御研究」中興 大学都市計画研究所修士論文

12）蔡仁毅（1993）「広告看板における都市景観の影 響の研究」『営建季刊』pp.25-47

13）蔡仁毅（1994）「都市景観から広告看板の設置と その影響の研究」『中華民国建築師雑誌』(上：8 月, pp.60-65, 下： 9 月, pp.96-99)

14）郭瑞坤（1994）「アニメーションと視覚模擬にお ける都市景観評価の応用」中山大学 委託調査報 告書

15）郭瑞坤（1996）「アニメーションと視覚模擬にお ける都市景観評価の応用」建築学報 pp.69-82

16）鄭偹平（1995）「景観模擬評価景観制度の研究」 成功大学都市計画研究所修士論文 
17）林晏州（1996）「街路樹の景観美の評価」台湾大 学 委託調查報告書

18）章錦瑜（1997）「台中市道路景観美質の評価」東 海学報 pp. $25-36$

19）李素馨（1997）「都市視覚景観に関する好みの研 究」逢甲大学 委託調査報告書

20）候錦雄（1997）「住民が公園景観維持の参加意欲 に関する研究」東海大学 委託調查報告書

21）周菊香（1997）『府城今昔』台南市政府

22）篠原修（編）（2000）『景観用語事典』彰国社, p.72

23）熊谷完士（1981）「商業地景観の評価に関する研
究」, 筑波大学社会工学類卒業論文

24）劉淑恵（1989）「住民評価に上る商業地景観整備 方策に関する研究」筑波大学環境科学研究科修士 論文

25）浅見泰司，瀬川祥子（1998）「少子化現象と住宅 事情」『住宅土地経済』NO.29, pp.26-33

26）藤島亥治郎（1993）『台湾的建築』台原出版社

27）徐正光（1995）「台湾の族群関係」『台湾史と台湾 史料 (二)』呉三連台湾史料基金会，pp.241 281

28）王甫昌（1998）「族群意識，民族主義與政党支持」 『台湾社会学研究』第 2 期 pp.1-45 